\title{
2-6 EL
}

\section{2-6-1 無機 EL}

田中省 作 $^{\dagger}$

\section{1. ま え がき}

EL ディスプレイは完全な固体デバイスであり, 高 信頼度, 高コントラスト, 高解像度を同時に満たし, また, 動作速度が速い, 自発光, などの優れた特徵を 有しているため, ワークステーションなどの OA 機 器用, 工作機械などの FA 機器用のディスプレイとし て実用化されている。しかし，実用化されているのは モノクローム(黄橙色) EL ディスプレイに限られてお り, ELディスプレイの本格的な普及のためには, カ ラーEL ディスプレイの実現が不可欠の課題である.

$\mathrm{ZnS}: \mathrm{Mn}$ 薄膜は黄橙色の高輝度・高効率 $(4 \sim 5$ $\mathrm{lm} / \mathrm{W})$ の $\mathrm{EL}$ 発光を示す.この $\mathrm{ZnS}: \mathrm{Mn}$ 薄膜 $\mathrm{EL}$ 材料を用いてモノクローム薄膜 EL ディスプレイが実 用化され，すでに 10 年以上が経過した。モノクロー ム EL の最近の進展としては, 素子特性の向上より, むしろ駆動方法や EL パネルの設計・製造技術の改良 による, 大型化, 高精細化, 高輝度化, 低消費電力化 が著しい。

カラー薄膜 EL ディスプレイを実現するために, 2 つの方法が研究されている. ひとつは, 赤, 緑, 青色 の三原色の EL 材料を用いるものであり, 他のもの は, 白色発光薄膜 $\mathrm{EL}$ と R/G/B カラーフィルタとの 組合せを用いるものである ${ }^{11}$ 。それぞれの構造に固有 の特徵, 解決すべき課題があるが, 市販レベルのカラ 一ELディスプレイが, これらの方法を用いて開発さ れている.

\section{2. 新しい青色 EL 材料の開発とフルカラー薄膜 EL ディスプレイ}

赤, 緑, 青色の三原色の $\mathrm{EL}$ 材料を用いて, カラー $\mathrm{EL}$ パネルを実現するためには, 三原色の発光を示す 高輝度・高効率な薄膜 $\mathrm{EL}$ 材料の開発が不可欠であ る. 赤/緑/青色発光薄膜 EL 材料の輝度と効率の現

$\dagger$ 鳥取大学 工学部 電気電子工学科

"2-6-1 Inorganic Electrolumimescent Displays" by Shosaku Tanaka (Department of Electrical and Electronic Engineering, Fuculty of Engineering, Tottori Uiniversity, Tottori)
表 1 赤/緑/青色発光薄膜 $\mathrm{EL}$ 材料の輝度 - 効率の現状

\begin{tabular}{|c|c|c|c|c|}
\hline 発光色 & EL 材料 & $\begin{array}{c}\text { 輝度 } \\
\left(\mathrm{cd} / \mathrm{m}^{2}\right)\end{array}$ & $\begin{array}{c}\text { 効率 } \\
(\mathrm{lm} / \mathrm{W})\end{array}$ & $\begin{array}{c}\text { 色度座標値 } \\
(x, y)\end{array}$ \\
\hline 赤 & $\begin{array}{l}\mathrm{ZnS}: \mathrm{Mn} / \mathrm{CdSSe} \\
\text { フィルタ }\end{array}$ & 75 & \multirow[t]{2}{*}{0.8} & \multirow[t]{2}{*}{$(0.63,0.36)$} \\
\hline \multirow[t]{3}{*}{ 緑 } & $\mathrm{ZnS}: \mathrm{TbOF}$ (SP) & 100 & & \\
\hline & $\mathrm{ZnS}: \mathrm{TbS}$ (ALE) & 70 & \multirow[t]{4}{*}{$\sim 1$} & \multirow[t]{2}{*}{$(0.32,0.60)$} \\
\hline & $\mathrm{ZnS}: \mathrm{Tb}, \mathrm{F}(\mathrm{SP})$ & 70 & & \\
\hline \multirow[t]{2}{*}{ 青 } & $\mathrm{SrS}: \mathrm{Ce}, \mathrm{K}$ & 6 & & $(0.10,0.15)$ \\
\hline & $\mathrm{CaGa}_{2} \mathrm{~S}_{4}: \mathrm{Ce}$ & 10 & & $(0.14,0.19)$ \\
\hline
\end{tabular}

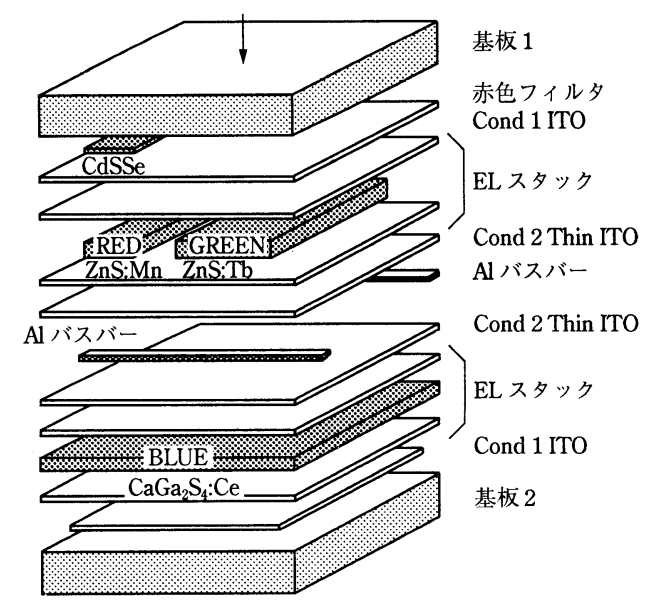

図 1 2 枚の基板を用いたフルカラーEL ディスプレ イの構造 ${ }^{2}$ (一方の基板に緑色 $(\mathrm{ZnS}: \mathrm{Tb})$ と 赤色 $(\mathrm{ZnS}: \mathrm{Mn} / \mathrm{CdSSe}$ フィルタ) $\mathrm{EL} の$ 画素 を配列し，他方の基板に青色 $\left(\mathrm{CaGa}_{2} \mathrm{~S}_{4}\right.$ : Ce）ELの画素を配列している)

状, 色度座標值を表 1 に示す。これまで, フルカラー EL ディスプレイの開発が困難であったのは, 充分 な, 輝度・効率をもつ青色 EL 材料がなかったことに よる.この問題に対するブレークスルーとして, 新し い青色 $\mathrm{EL}$ 材料である $\mathrm{CaGa}_{2} \mathrm{~S}_{4}: \mathrm{Ce}$ が見いだされ た2).これらのEL材料を用いて, 対角 10 インチ, $640(\times 3) \times 480$ のフルカラー (16 色) EL ディスプレ イが試作された，ELパネルの構造を図 1 に示す。緑 
RGB カラーフィルタ

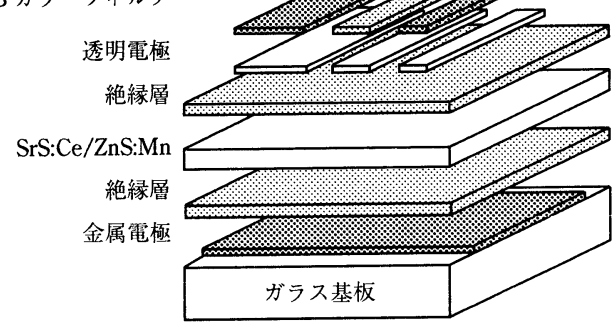

図 $2 \mathrm{SrS}: \mathrm{Ce} / \mathrm{ZnS}: \mathrm{Mn}$ 積層構造薄膜 $\mathrm{EL}$ と力ラー フィルタを組合せたカラーEL ディスプレイの 構造 ${ }^{5)}$

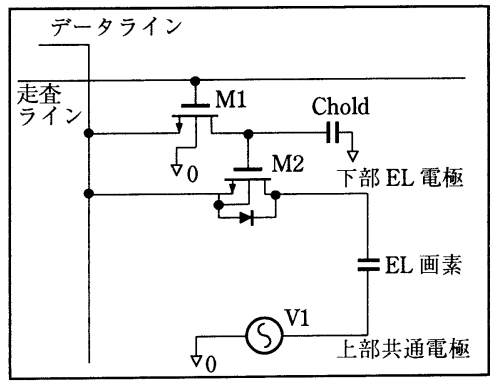

(a)

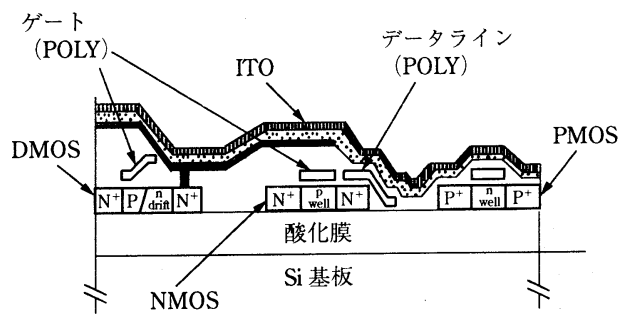

(b)

図 3 アクティブマトリックス ELディスプレイ (AMEL) の（a )画素駆動回路と, (b ) 素子断 面の構造?

色と赤色 EL の画素を配列した基板と青色 EL の基板 とを組合せた，二重基板構造になっている．緑色 $\mathrm{EL}$ 材料には $\mathrm{ZnS}: \mathrm{Tb}$, 赤色 $\mathrm{EL}$ 材料には $\mathrm{ZnS}: \mathrm{Mn} /$ CdSSe フィルタが用いられている. 青色 EL 材料 $\mathrm{CaGa}_{2} \mathrm{~S}_{4}$ : Ce の特性改善が進み, 対角 5 インチ, 画 素数 $320(\times 3) \times 256$ のカラーEL ディスプレイが市 販されるようになった ( $^{3)}$. 輝度は $30 \mathrm{~cd} / \mathrm{m}^{2}$ であり, 高いコントラスト比 $(20: 1$ at $500 \mathrm{~lx})$ と広い視野 角という特徵を活かした, 医療機器などのディスプレ イへの応用が期待される.

また，青色 $\mathrm{EL}$ 材料として従来の $\mathrm{SrS}$ ：Ce を使用 して, 同様な構造の車載用の $\mathrm{R} / \mathrm{G} / \mathrm{B}$ マルチカラー
EL ディスプレイの開発も進められている4).

\section{3. 白色 EL とカラーフィルタを組合せた フルカラー薄膜 EL ディスプレイ}

白色発光薄膜 EL とカラーフィルタを組合せたフル カラーELディスプレイについても進展が見られる. $\mathrm{EL}$ パネルの構造を図 2 に示す5). ITO 透明電極と金 属電極を入れ換えた反転構造と呼ばれる構造を有する 薄膜 EL と, シール用のカバーガラスに形成したカラ ーフィルタとの組合せを用いている。この構造では， 青から赤色領域にスペクトル成分を有する, 白色発光 薄膜 EL の発光をカラーフィルタにより $\mathrm{R} / \mathrm{G} / \mathrm{B}$ 三原 色に分離する。このため, EL パネルの製造上の観点 からは, 複雑さが少ないといえる. 視差による混色を 避けるため, フィル夕は薄膜 ELに接するようにシー ル用のカバーガラスに形成する. また, この構造は次 のような特幑を有する。

(a) カラーフィル夕を有するので, 円偏光フィル タなしで，非常に良いコントラストを示す.

(b) $R / G / B$ 画素に同一の特性をもつ白色発光薄 膜 ELを用いるので, 駆動回路が簡単化でき, 経時特性にも優れている.

一方, この構造の問題は, 高い輝度をもつ白色発光 薄膜 EL を必要とする点にある.

白色発光薄膜 $\mathrm{EL}$ 材料としては, $\mathrm{SrS} ： \mathrm{Ce} / \mathrm{ZnS}$ ： $\mathrm{Mn}$ の積層発光層を用いる. SrS : Ce 発光層による青 緑色の発光と $\mathrm{ZnS} ： \mathrm{Mn}$ による黄橙色の発光が重なっ た，幅広いスペクトル分布をもつ白色 ELが得られ る. ALE 法で作製した白色 ELを用いて, カラーEL パネルが開発された ${ }^{5)}$. 対角 10 インチ, 画素数 $320(\times 3) \times 256$, 輝度 $21 \mathrm{~cd} / \mathrm{m}^{2}$ (赤色 $7 \mathrm{~cd} / \mathrm{m}^{2}$, 緑 色 $11 \mathrm{~cd} / \mathrm{m}^{2}$, 青色 $\left.3 \mathrm{~cd} / \mathrm{m}^{2}\right)$, コントラスト比 30 : 1 (at $1000 \mathrm{~lx}$ ) である. 輝度はやや低いが, 明るい環 境下でも高いコントラスト比を保つ特徵がある。

これまで, $\mathrm{SrS}: \mathrm{Ce} / \mathrm{ZnS}: \mathrm{Mn}$ の積層発光層の長期 信頼性 (寿命特性)が不充分とされてきたが, 最近, 30,000 時間を超える寿命を持つことが示され，モノ クロームELディスプレイと同様な高い信頼性をもっ たディスプレイとして実用化されるものと期待され る).

\section{4. アクティブマトリックス駆動薄膜 EL ディスプレイ}

薄膜 EL ディスプレイは, その機能部分の薄膜の厚 さが $1 \sim 2 \mu \mathrm{m}$ であるため, 画素サイズが $10 \times 10 \mu \mathrm{m}^{2}$ 程度の超高精細 (高解像度)ディスプレイを比較的容易 
に実現することができる。このような薄膜 EL の特徴 をいかした、ヘッドマウンテッドディスプレイ (Head Mounted Display: HMD)への応用が試みられてい る. SOI (Silicon on Insulator) 技術を用いて $\mathrm{Si}$ 基板 上に, EL 素子駆動用の高耐圧 DMOS-FET とデータ 用のCMOS-FET を集積し，その上に EL 素子を集 積した,アクティブマトリックス駆動の EL ディスプ レイ(AMEL)が開発された7). 画素の駆動回路を図 3 (a)に, 素子断面の構造を図 3(b)に示す。この AMELを用いて, HMD 用のELディスプレイが試 作された. 画素数は $1280 \times 1024$, 表示面積は $1.2 \times$ 1.0 インチ $\left(30 \times 25 \mathrm{~mm}^{2}\right)$ であり, 画素ピッチ（分

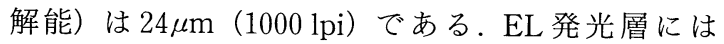
$\mathrm{ZnS}$ ：Tbを用いている. AMEL を用いることにより メモリー駆動が可能となり, AC-PDP と同様なサブ フィールドを用いた輝度データの書込みと発光回数の 制御で, 64 階調（6ビット）の中間調が得られてい る.駆動周波数は $3 \mathrm{kHz}$ であり, 輝度は $140 \mathrm{~cd} / \mathrm{m}^{2}$, コントラスト比は $>100 ： 1$ である. 重量は $6 \mathrm{~g}$, 消費 電力は $2 \mathrm{~W}$, 周辺部を含めたサイズも $1.3 \times 1.1$ イン チ $\left(33 \times 28 \mathrm{~mm}^{2}\right)$ とコンパクトである.

この $\mathrm{EL}$ パネルは基本的に反転構造であるので, 白 色 EL と, カラーフィルタと組合せてフルカラー化も 可能であり, HMD 用の $640(\mathrm{R} / \mathrm{G} / \mathrm{B}) \times 480$ のフル カラーAMELも開発されている8).

（1996 年 12 月 16 日受付）

\section{〔参 考 文 献〕}

1) C. N. King: "Electroluminescent Displays", 1992 SID Seminar Lecture Notes, pp. M-6/1-6/36
2) W. A. Barrow, R. C. Coovert, E. Dickey, C. N. King, C. Laakso, S. S. Sun, R. T. Tuenge, R. Wentross and J. Kane: "A New Class of Blue TFEL Phosphors with Application to a VGA Full-Color Display", Digest of Tech. Papers, 1993 SID Int. Symposium, pp. 761764 (1993)

3) W. A. Barrow, R. C. Coovert, E. Dickey, T. Flegal, M. Fullman, C. N. King, and C. Laakso: "A High Contrast, Full Color 320. 256 Line TFEL Display”, Proc. 14 th Int. Display Research Conf., pp. 448-451 (1994)

4) A. Kato, M. Katayama, K. Sugiura, K. Inoguchi, H. Ishihara, N. Ito and T. Hattori: "An RGB 8-Color EL Display in a Stacked Panel Configuration Using Unfiltered SrS: Ce", Proc. 15 th Int. Display Research Conf., pp. 287-290 (1995)

5) J. Haaranen, T. Harji, P. Heikkinen, G. Harkonen, M. Leppanen, T. Lindholm, J. Maula, J. Maattanen, A. Pakkala, E. Soininen, M. Soininen, R. Tornqvist and J. Viljanen: "512 $(\times 3) \times 256$ RGB Multi-color TFEL Display Based on Color by White", Digest of Tech. Papers, 1995 SID Int. Symposium., pp. 883-886 (1995)

6) A. Mikami, I. Yashima and F. Kajikawa: "New Developments in ZnS Type EL Displays" Proc. 8 th Int. Workshop on Inorganic and Organic Electroluminescence., pp. 369373 (1996)

7) R. Khormaei, S. Thayer, K. Ping, C. N. King, G. Dolny, A. Ipri, S. Hsueh, R. Stewart, T. Keyser, G. Becker, D. Kagey and M. Spitzer: "High-Resolution Active-Matrix Electroluminescent Display", Digest of Tech. Papers, 1994 SID Int. Symposium, pp. 137-139 (1994)

8) M. Aguilera, B. Aitchison, D. Basham, S. Moehnke, K. Ping, R. Tuenge, W. Vetanen and C. N. King: "An RGB Color VGA Active-Matrix EL Display”, Digest of Tech. Papers, 1996 SID Int. Symposium, pp. 125-128 (1996)

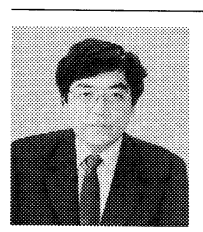

奋中妿省作 1972 年, 鳥取大学工学部電 子工学科卒業. 1973 年, 同専攻科修了. 同 年, 鳥取大学工学部に勤務。現職は教授。半 導体光物性の研究, ならびに電子ディスプレ イ, とくに薄膜 EL の研究に従事. 理学博 士.

\section{2-6-2 有機 EL}

\section{1. ま え がき}

有機 EL 素子は直流で駆動する一種の発光ダイオー ドであり，有機 LED とも呼ばれる．無機 EL 素子は 薄膜型やポリマー分散型がすでに実用化されており，

† 山形大学 大学院工学研究科

“2-6-2 Organic EL” by Junji Kido (Graduate School of Engineering, Yamagata University, Yamagata)

\section{城 戸 淳 二十}

単に EL 素子というと無機 EL 素子を指す場合が多い が，交流駆動する無機 EL とは使用する材料や動作機 構の点で大きく異なる.

動作機構はキャリヤ注入型であり，陰極および陽極 からそれぞれ電子とホールが有機発光層中に注入さ れ，再結合することにより励起子を生ずる。したがっ て, 高効率を達成するには発光層へのバランス良い両 キャリヤの注入が必要不可欠であり，そのための素子 